\title{
Introdução ao Processo Coletivo Passivo: a experiência do direito norte-americano e a ações coletivas passivas no atual estágio do processo coletivo no Brasil
}

\author{
Introduction to the Defendant Class Actions: the \\ north-american's law experience and the defendant \\ class actions in the current stage of micro system \\ collective procedure in Brazil
}

\section{Resumo}

No presente trabalho abordamos o tema das ações coletivas passivas - ações propostas contra um grupo ou classe. Indiscutivelmente o processo coletivo no Brasil alcançou significativo grau de sofisticação, sendo, inclusive, considerado modelo para os outros países de "civil law". Nada obstante, inexistem disposições legais acerca dessas ações. Essa ausência de regulamentação pode ser explicada pelo fato de o processo coletivo inicialmente ter sido pensado para que a coletividade ocupe o polo ativo; porém, por vezes pode ser útil ou até mesmo necessário que as ações coletivas passivas sejam admitidas - sob pena de se inviabilizar a tutela de determinados direitos/interesses lesionados ou ameaçados de lesão. A realidade do foro já demonstra que, apesar a ausência de disposições expressas acerca do assunto, as ações coletivas passivas já são uma realidade na prática - v.g., ações possessórias propostas contra coletividades indeterminadas ou ações rescisórias de ação coletiva ativa. Ademais, as ações coletivas passivas guardam algumas semelhanças com as "defendant class actions" norte-americanas - o que faz com que a experiência estadunidense seja um fértil campo de estudos para os interessados no assunto. Existem fortes argumentos que defendem a admissão de "lege lata" das ações coletivas passivas; contudo, futura regulamentação legal será importante para delimitar e clarificar a incidência desse fenômeno, que - no atual estágio do microssistema de processos coletivos brasileiro - causa várias dificuldades de ordem processual, principalmente no que tange a legitimidade e a coisa julgada.

Palavras-chave: Processo civil. Tutela coletiva. Ação coletiva passiva.

\section{Abstract}

In the present work we address the subject of defendant class actions - lawsuits that are filed against a group or class of people. The collective procedure in Brazil has reached a meaningful degree of sophistication, being even considered a model for other civil law countries. Nevertheless, there are no legal provisions concerning defendant class actions. That lack of regulation can be explained by the fact of collective guardianship of rights having first been thought for the collectivity to occupy the plaintiff spot in the procedure; however, sometimes, the admission of defendant class actions might be useful or even necessary - otherwise, the protection of some violated or threatened rights/interests could remain impossible. The court reality already demonstrates that despite the lack of express legal provisions concerning the subject, defendant class actions already exist in practice - v.g., possessive actions filed against undetermined collectivities or motions to set aside judgments of regular class actions. Furthermore, Brazilian defendant class actions hold some similarities with their North American counterparts - which makes the U.S. experience to be a fertile field of studies for those interested in the subject. There are strong arguments for admitting "lege lata" of defendant class actions; yet, future legal ruling will be important to delimit and clarify the incidence of such phenomenon, which - at the current stage of the Brazilian collective procedure micro system - causes several procedural difficulties, especially regarding legitimacy and res judicata.

Keywords: Civil procedure. Collective guardianship of rights. Defendant class action.

Mestrando em Direito Processual Civil pela UFPR, membro do Núcleo de Direito Processual Civil Comparado da mesma instituição e assessor de Desembargador no TJPR.. 


\section{Introdução ao Processo Coletivo Passivo}

Hodiernamente proliferam conflitos de massa que demandam a criação de instrumentos capazes de proteger os novos direitos (novos interesses). ${ }^{2}$ Nos ordenamentos de civil law, o processo civil clássico não foi capaz de oferecer uma tutela adequada a interesses que não possuem um titular determinado, ou mesmo a interesses individuais de pequena expressão. Nessa linha, Remo Caponi ${ }^{3}$, em palestra proferida na Faculdade de Direito da Universidade Federal do Paraná, ressaltou que, nos sistemas jurídicos de matriz romano-germânica, o processo civil tradicionalmente foi pensado com objetivo de lidar com direitos subjetivos, o que enseja grandes dificuldades quando se busca tutelar bens que não podem ser apropriados individualmente.

Conforme o magistério de Alcides Alberto Munhoz da Cunha, pode-se afirmar que essa predileção do processo civil liberal pela exclusiva tutela de pretensões individuais decorre do próprio direito material, que demorou a voltar seus olhos aos interesses meta-individuais. Tradicionalmente poucas situações jurídicas plurissubjetivas encontravam-se tuteladas, tais como, nas palavras do processualista, [...] certas relações envolvendo condôminos diante da coisa comum; relações envolvendo coerdeiros diante da heranças; certas relações envolvendo os sócios diante das deliberações de assembleia de sociedade etc. ${ }^{4}$

Frise-se que o citado individualismo do direito material está umbilicalmente ligado aos valores consagrados pelas revoluções do século XVIII. ${ }^{5}$ As grandes codificações findaram por erigir um projeto jurídico-político pautado pela ligação entre a propriedade privada e a liberdade do indivíduo. ${ }^{6}$

Sobre essa conjuntura teoriza Eroulths Cortiano Júnior:

2 ARENHART, Sérgio Cruz. Perfis da tutela inibitória coletiva. São Paulo: RT, 2006. p.138.

3 Remo Caponi. Palestra "A experiência da class action na jurisprudência italiana”. 2012.

4 CUNHA, Alcides Alberto Munhoz. Evolução das ações coletivas no Brasil. Revista de Processo, São Paulo, v. 77, p. 2-3, 1995.

5 VENTURI, Elton. Processo civil coletivo: a tutela jurisdicional dos direitos difusos, coletivos e individuais homogêneos no Brasil. Perspectivas de um Código Brasileiro de Processos Coletivos. São Paulo: Malheiros, 2007. p. 26. terza, 2010. p. 70.

O circulo fecha-se com a concepção individualista da sociedade. As regras abstratas dirigem-se a um sujeito abstrato, cuja ação serve para movimentar todo o capital de garantias estabelecidas na ordem medieval. A ação é individual porque se concebe o indivíduo como absolutamente livre de qualquer liame social, político ou econômico. A liberdade de iniciativa no campo econômico a autonomia da vontade no plano jurídico. Tutela-se a liberdade de ação, e se antes os indivíduos estavam ligados à terra ou a outrem pela força da coerção (econômica ou social), esta ligação agora surge da própria vontade individual.

A influência de tais valores na seara do processo civil foi tão marcante que, nos séculos XVIII e XIX, chegou-se ao ponto de se enxergar o processo como um contrato, no sentido que as partes, mediante a celebração de um negócio jurídico, submeter-se-iam ao processo pela autonomia da vontade. ${ }^{8}$

Nada obstante, enquanto o processo civil dos países de civil law estava dominado pelo individualismo; na common law exsurgiram as primeiras formas de tutela coletiva. No direito inglês a origem das class actions remonta ao século XVII. Ato contínuo, tais ações foram paulatinamente aprimoradas, em especial nos Estados Unidos. ${ }^{9}$

No Brasil, a primeira forma de tutela judicial de interesses coletivos, afora as ações de controle de constitucionalidade, deu-se por meio da ação popular (Lei 4.717/1965), cuja titularidade é do cidadão e que, em sua configuração atual, presta-se à tutela do patrimônio público, da moralidade administrativa, do patrimônio histórico e cultural e do meio ambiente. Tal ação tem utilidade diminuta na medida em que dificilmente o cidadão terá condições de arcar com um processo de tal magnitude. ${ }^{10}$

O citado defeito foi mitigado com a promulgação da Lei da Ação Civil Pública (Lei 7.347/1985). Atualmente, diante da introdução do art. 110 do Código de Defesa de Consumidor (CDC), que inseriu o inciso IV do art. 1. ${ }^{\circ}$ da Lei 7.347/85, a ação civil pública vocaciona-se à tutela

CORTIANO JÚNIOR, Eroulths. O discurso jurídico da propriedade e suas rupturas: uma análise do ensino do direito de propriedade. Rio de Janeiro: Renovar, 2002. p. 82-83.

8 CINTRA, Antônio Carlos de Araújo; DINAMARCO, Cândico Rangel; GRINOVER, Ada Pellegrini. Teoria geral do processo. 26. ed. São Paulo: Malheiros, 2010. p. 333.

9 ARENHART, Sérgio Cruz. Perfis da tutela inibitória coletiva. São Paulo: RT, 2006. p. 151.

10 MARINONI, Luiz Guilherme; ARENHART, Sérgio Cruz. Curso de processo civil: procedimentos especiais. 3. ed. São Paulo: Revista dos Tribunais, 2012. v. 5. p. 304 . 
de quaisquer interesses coletivos ${ }^{11}$; ressalvadas as hipóteses que envolvam tributos, contribuições previdenciárias, pretensões relativas ao Fundo de Garantia por Tempo de Serviço (FGTS) e outros fundos de natureza institucional cujos titulares podem ser individualmente considerados - conforme a dicção do parágrafo único da referida lei, incluído pela enfadonha medida provisória n. ${ }^{\circ}$ 2.180-35 de 2001, que veio a enfraquecer a potencialidade do processo coletivo.

Na década de 1990, o citado Código de Defesa do Consumidor passou a ser parte integrante daquilo que veio a ser chamado de microssistema brasileiro de processos coletivos (hoje composto ainda pelos seguintes diplomas legislativos: Lei 7.853/89 - que trata das pessoas portadoras de deficiências; Lei 7.913/89 - que disciplina os investidores do mercado imobiliário; Lei 8.8069/89 - Estatuto da Criança e do Adolescente; Lei 8.429/92 Lei da Improbidade Administrativa; Lei 8.884/94 - que trata da ordem econômica e da livre concorrência; Lei 10.257/01 - Estatuto da Cidade; Lei 10.741/03 - Estatuto do Idoso; Lei 10.671/03 - Estatuto de Defesa do Torcedor; entre outros). ${ }^{12}$

O Código de Defesa do Consumidor trouxe a conceituação dos interesses difusos, coletivos e individuais e homogêneos, algo motivado pela grande divergência doutrinária existente à época acerca dessas categorias, o que poderia gerar obstáculos à aplicabilidade prática do processo coletivo. ${ }^{13}$

Frise-se que o CDC, em seu art. 81, traz a expressão interesses ou direitos. Segundo Elton Venturi, essa opção explica-se pela tradicional associação dos direitos subjetivos a pretensões individuais auferíveis economicamente. Ocorre que as pretensões de cunho meta-individual não são titularizadas de forma individual e tardaram a receber proteção jurídica - o que fez com que a doutrina optasse pela expressão interesses. ${ }^{14}$ Ademais, o cuidado do legislador em positivar as duas expressões está correla-

LEONEL, Ricardo de Barros. Manual do processo coletivo. 2. ed. São Paulo: Revista dos Tribunais, 2011. p. 111.

12 LEONEL, Ricardo de Barros. Manual do processo coletivo. 2. ed. São Paulo: Revista dos Tribunais, 2011. p.111.

13 GRINOVER, Ada Pellegrini et al. Código brasileiro de defesa do consumidor: comentado pelos autores do anteprojeto. 4. ed. Rio de Janeiro: Forense Universitária, 1995. p. 494.

14 VENTURI, Elton. Processo civil coletivo: a tutela jurisdicional dos direitos difusos, coletivos e individuais homogêneos no Brasil: perspectivas de um código brasileiro de processos coletivos. São Paulo: Malheiros, 2007. p. 46. cionada à influência exercida por autores de alguns países europeus - como a Itália - que, ao lado do Poder Judiciário, convive com uma Justiça Administrativa. Conforme o magistério de Celso Antônio Bandeira de Mello, nos ordenamentos em que há dualidade de jurisdição, incumbe ao juiz ordinário decidir sobre questões atinentes a direitos subjetivos; de outra monta, em sede de interesses legítimos, a jurisdição é exercida pelo juiz administrativo. Ao passo que no Brasil prevalece a unidade da jurisdição, a diferenciação entre interesses e direitos não possui grande relevância. ${ }^{15}$

O inciso I do parágrafo único do art. 81 do CDC conceitua como interesses ou direitos difusos os transindividuais, de natureza indivisível, de que sejam titulares pessoas indeterminadas e ligadas por circunstâncias de fato. Tais interesses são indivisíveis e caracterizados pela indeterminação dos titulares - que não estão ligados por uma relação jurídica base. ${ }^{16}$

Os interesses coletivos estão previstos no inc. II do parágrafo único do art. 81 do CDC. São direitos transindividuais de natureza divisível de que seja titular grupo, categoria ou classe de pessoas ligadas entre si ou com a parte contrária por uma relação jurídica base. Os titulares desses interesses são indeterminados, porém determináveis. O bem jurídico tutelado é indivisível. Os interesses coletivos se diferem dos difusos na medida em que naqueles existe uma relação jurídica base que une os titulares do interesse coletivo. ${ }^{17}$

Já os interesses individuais e homogêneos são direitos individuais cuja tutela é viabilizada pela via coletiva. O inc. III do parágrafo único do art. 83 do CDC destaca a origem comum desses direitos, o que, conforme os autores do anteprojeto do diploma consumerista, não pressupõe uma unidade factual ou temporal, pois a violação ou ameaça ao direito das vítimas pode ocorrer, por exemplo, em dias e locais diferentes. O que interessa é a origem comum das violações ou ameaças. ${ }^{18}$

Como visto, não obstante algumas manobras po-

15 MELLO, Celso Antônio. Curso de direito administrativo. 29 ed. São Paulo: Malheiros, 2012. p. 968.

16 GRINOVER, Ada Pellegrini et al. Código brasileiro de defesa do consumidor: comentado pelos autores do anteprojeto. 4. ed. Rio de Janeiro: Forense Universitária, 1995. p. 502.

17 LEONEL, Ricardo de Barros. Manual do processo coletivo. 2. ed. São Paulo: Revista dos Tribunais, 2011. p.96.

18 GRINOVER, Ada Pellegrini et al. Código brasileiro de defesa do consumidor: comentado pelos autores do anteprojeto. 4. ed. Rio de Janeiro: Forense Universitária, 1995. p. 506. 
líticas $^{19}$ que buscaram enfraquecer o microssistema de tutela coletiva (v.g., a limitação territorial dos efeitos da coisa julgada coletiva ou impossibilidade de veiculação de pretensões de natureza tributária, previdenciária e relacionadas ao FGTS em sede de ação civil pública), o processo coletivo brasileiro foi constantemente aprimorado ao longo dos anos, atingindo significativo grau de sofisticação.

Nessa linha, teorizam Luiz Guilherme Marinoni e Sergio Cruz Arenhart:

A ação coletiva, pois, pode veicular quaisquer espécies de pretensões imagináveis, sejam elas inibitória-executiva, reintegratória, do adimplemento na forma específica, ou ressarcitória (na forma específica ou pelo equivalente monetário). Todas podem ser prestadas por qualquer sentença adequada (inclusive, portanto, pelas sentenças mandamental e executiva). Admitem, ainda, pretensões declaratórias e constitutivas. ${ }^{20}$

Porém, é indiscutível que esse microssistema de tutela coletiva foi pensado para que o polo passivo das demandas seja ocupado pelo representante da coletividade.

${ }^{21}$ Para Camilo Zufelato, essa opção justifica-se, pois, na medida em que se buscou criar mecanismos para tutela de direitos transindividuais e fortalecer as organizações sociais, admitir que estas pudessem ocupar o polo passivo em demandas coletivas poderia frear o desenvolvimento do sistema. ${ }^{22} \mathrm{O}$ fato de o processo coletivo inicialmente

19 Para uma reflexão crítica sobre o assunto ver: GRINOVER, Ada Pellegrini. A ação civil pública refém do autoritarismo. Revista de Processo, v. 96, p-28-36, 1999.

20 MARINONI, Luiz Guilherme; ARENHART, Sérgio Cruz. Curso de processo civil: procedimentos especiais. 3. ed. São Paulo: Revista dos Tribunais, 2012. v. 5. p. 315.

21 Para Aluísio de Castro Mendes, a própria dicção de alguns artigos da Constituição Federal atesta essa realidade: "Isso [o fato de o processo coletivo ter sido inicialmente pensando para que uma coletividade ocupe o sempre o polo ativo] fica claro, por exemplo, no próprio texto constitucional vigente, quando se menciona que 'qualquer cidadão é parte legítima para propor ação popular', nos termos do art. $5 .^{\circ}$, LXXIII, da Carta Magna, ou, conforme inc. LXXX, que 'o mandado de segurança coletivo pode ser impetrado por', bem como, no art. 129, III, ao dispor, como função institucional do Ministério Público, 'promover o inquérito civil e a ação civil pública, para a proteção do patrimônio público e social, do meio ambiente e de outros interesses difusos e coletivos." MENDES, Aluisio Gonçalves de Castro . A legitimação, a representatividade adequada e a certificação nos processos coletivos e as ações coletivas passivas. Revista de Processo, Cidade, v. 209, p. 243-265, 2012. p. 259.

22 ZUFELATO, Camilo. Ação coletiva passiva no direito brasileiro: necessidade de regulamentação legal. In: GOZZOLI, Maria Clara et al. (Org.). Em defesa de um novo sistema de processos coletivos: estudos em homenagem a Ada Pelle- ter sido pensando para que o grupo ocupe o polo ativo da relação jurídico processual igualmente decorre de uma visão que enxerga a coletividade como vítima - o que não deixa de ser verdade na maioria dos casos.

Não obstante, a realidade do foro demonstra que, em inúmeras circunstâncias, admitir que uma coletividade ocupe o polo passivo de uma demanda pode ser interessante ou até mesmo necessário ${ }^{23}$, do contrário a adequada tutela de determinado direito material lesionado ou ameaçado de lesão poderá restar inviabilizada.

Como exemplo desse fenômeno, podemos citar a ação civil pública proposta pelo Ministério Público de Minas Gerais em face das repúblicas estudantis de Diamantina-MG. ${ }^{24}$ Para inibir danos ao patrimônio histórico de cidade, o Juiz da $1^{\circ}$ Vara Cível e Crime da comarca de Diamantina deferiu liminar ordenando que as repúblicas estudantis fossem desocupadas durante o Carnaval de 2012. O parquet havia recomendado que as repúblicas que pretendessem vender pacotes para o Carnaval obtivessem alvará municipal e laudo do corpo de bombeiros. Todavia, essa recomendação foi desrespeitada e as repúblicas venderam indiscriminadamente pacotes de estadia e de festas pela Internet. Na opinião do ente ministerial, o elevado contingente de foliões somado à desordenada ocupação do espaço histórico poderia ensejar danos irreparáveis ao patrimônio histórico e cultural da cidade. A adequação da medida justificou-se pela impossibilidade em se identificar todos os réus. As repúblicas estudantis foram consideras o núcleo dos interesses envolvidos.

Por outro lado, no julgamento da Ação Civil Pública n. ${ }^{\circ}$ 0006101-51.2005.4.05.8100, em trâmite na $18 .^{\mathrm{a}}$

grini Grinover. São Paulo: Saraiva, 2010. p. 89.

23 O estudo de casos concretos apresenta-se como interessante expediente destinado à compreensão do tema do presente trabalho. Sobre o estudo do direito a partir de casos, coadunamos com as seguintes considerações tecidas por Luciano de Camargo Penteado em obra destinada ao estudo do Direito das Coisas: "O direito normalmente tem sido estudo a partir da lei. Parte-se dela para depois, com a citação de jurisprudência, exemplificar o que passa. Trata-se, assim, o caso concreto, de modo residual, dando-se pouco valor à perspectiva judicial que o sistema de direito apresenta. Entretanto, muitas vezes, é preciso inverter a ordem para pensar o direito a partir do caso concreto, para dele extrair as generalizações necessárias ao conhecimento científico". PENTEADO, Luciano de Camargo. Direito das coisas. 2. ed. São Paulo: Revista dos Tribunais, 2012. p. 35.

24 Ação Civil Pública nº 0009909-46.2012.8.13.0216, em trâmite na $1^{\circ}$ Vara Cível, Crime e VEC da comarca de Diamantina-MG. 
Vara Federal do Ceará, proposta pela Superintendência Estadual do Meio Ambiente (SEMACE), Estado do Ceará e Instituto de Meio Ambiente (IBAMA) em face de alguns réus identificados e de todos os degradadores que possuem imóveis em área de mangue e terrenos de marinha na localidade de Maceió, verifica-se que a solução adotada foi outra. Da leitura do relatório da decisão infere-se que foi deferida liminar para determinar a suspenção de atividades, obras ou empreendimentos na área, bem como determinar a abstenção de realização de reformas ou ampliações das edificações existentes. Contudo, em cognição exauriente, o juízo a quo limitou-se a examinar os pedidos relativos aos réus identificados. Porém, no caso em análise, há de se concordar que solução diversa da adotada poderia gerar sérios problemas de representatividade adequada. A seguir transcrevemos relevante parcela da sentença:

A petição inicial faz menção genérica aos integrantes do polo passivo - "degradores (sic) que possuam imóveis em área de mangue e terrenos de marinha na localidade Maceió" (f.3) - e veicula pedidos em face de réus "nominados e os a serem identificados mediante inquérito civil" (f.29). Embora se creia decorrer mais de atecnia do que deliberada escolha dos autores, o teor da petição inicial leva à constatação de caracterização de "ação coletiva passiva", pela qual haveria o ajuizamento de ação em face de interessados difusos e coletivos. Entretanto, embora tal hipótese seja viável no direito estrangeiro - notadamente no norte-americano - a doutrina mais abalizada rejeita tal hipótese no ordenamento brasileiro. [...] Logo, o julgamento da presente lide deve ter claros limites inter partes, abrangendo apenas e tão somente os réus devidamente qualificados nos autos e os pedidos que a eles se referem.

Ora, em uma lide, tal como a relatada nesse julgado, inelutavelmente a melhor solução é admitir que um ou mais membros de grupo réu representem em juízo os demais, todavia, a escolha dos representantes pelo autor da ação não pode se dar de forma aleatória. Sobre isso, assevera Sérgio Cruz Arenhart: "Entretanto, é claro que não se pode aceitar a citação de qualquer um dos membros do grupo, para esse fim [representar em juízo os demais]. Devem ser escolhidos, dentro do grupo, aqueles que (ao menos aparentemente) têm condições de promover a melhor defesa de todos." ${ }^{25}$

ARENHART, Sérgio Cruz. A tutela coletiva de interesses individuais: para além da proteção dos interesses individuais homogêneos. São Paulo: Revista dos Tribunais, 2013. p. 238.
Já na ação civil pública no $10.910 / 2012$, proposta pelo Ministério Público Federal em face da União e da Federação Brasileira de Bancos (FEBRABAN), pede-se que as instituições associadas à FEBRABAN e que não possuam via de trânsito exclusiva para os vigilantes e carros-fortes, fisicamente separada do público, abstenham-se de efetuar a atividade de carrego ou descarrego de valores durante o expediente de atendimento ao público. Caso o legitimado coletivo tivesse que demandar cada um dos bancos individualmente, dificilmente os resultados pretendidos poderiam ser alcançados, além do mais, existe grande risco de decisões contraditórias - o que representa um desprestígio à tutela jurisdicional. Some-se a isso o fato de a associação ré prever em seu estatuto a defesa de seus associados em juízo.

Outro exemplo peculiar à experiência brasileira diz com a propositura de ações petitórias ou possessórias contra coletividades indeterminadas. Indiscutivelmente a grande frequência desse tipo de demanda decorre da histórica desigualdade fundiária no Brasil, que dá azo a frequentes ocupações. Ocorre que, na prática, muitas dessas ações correm de forma unilateral, sem a citação dos réus; ou um movimento social sem personalidade jurídica é admitido como legitimado passivo. ${ }^{26}$

Cita-se também os interditos proibitórios manejados para defesa da posse diante piquetes ou invasões de empresas durante greves. Tais ações, conforme a dicção da súmula vinculante n. 23 do Supremo Tribunal Federal, devem ser processadas e julgadas pela Justiça do Trabalho. Diogo Campos Medina Maia lembra que, nesses casos, o polo passivo da demanda possessória em geral é composto pelo sindicato da categoria, que representa os trabalhadores que serão atingidos por eventual decisão, a qual, diante da fungibilidade característica das ações possessórias, poderá determinar a vedação da ameaça, a cessão da turbação ou a reintegração da posse. ${ }^{27}$

As ações citadas ${ }^{28}$ vêm sendo chamadas pela dou-

26 FORMACIARI, Flávia Hellmeister Clito. A representatividade adequada nos processos coletivos. 2009. 189 f. Tese (Doutorado) - Programa de Pós Graduação em Direito da Universidade de São Paulo. Disponível em: <www.teses. usp.br/.../Representatividade_Adequada_nos_Processos_ Coletivos.pdf $\geq$. Acesso em: 29 jul. 2012. p. 103.

27 MAIA, Diogo Campos Medina. Ação coletiva passiva. Rio de Janeiro: Lumen Juris, 2009. p. 45.

28 A doutrina elenca inúmeros exemplos que, a priori, seriam ações coletivas passivas. Não obstante a necessidade de maior reflexão teórica acerca da viabilidade de cada uma 
trina de ações coletivas passivas que, não obstante as profundas diferenças entre os sistemas processuais nas quais estão inseridas, guardam algumas semelhanças com as defendant class actions do direito norte-americano.

Nos Estados Unidos, as defedant class actions são propostas em proporção muito menor do que as plaintiff class actions (ações coletivas ativas). Porém, como observado por Antônio Gidi, a realidade social brasileira pode fazer com que esse instituto tenha ampla aplicabilidade em variadas situações. ${ }^{29}$

\section{A experiência do Direito do Trabalho}

O Direito do Trabalho e o Direito Processual do Trabalho há muito tempo admitem que uma categoria ocupe o polo passivo de uma demanda. Sustenta-se que, em certa medida, a compreensão da experiência dos dissídios coletivos de alguma forma pode ser útil ao estudo das ações coletivas passivas. ${ }^{30}$

das possibilidades cogitadas, Ricardo de Barros Leonel colecionou os exemplos citados pelos autores que escreveram sobre o assunto: "[...] ações propostas em face de associações que congregam torcidas organizadas de times de futebol, objetivando sua extinção por praticarem atos ilícitos; ações propostas por legitimados coletivos em face de entidades que congreguem coletividades integradas por determinado segmento de atividade econômica (por exemplo, demanda aforada pelo Ministério Público ou associação de defesa dos consumidores contra a Federação de Bancos ou dos prestadores de serviços ou seguros de saúde), para fins de imposição de condutas ou procedimentos a todas as instituições congregadas (instituições financeiras ou seguradoras de saúde); ações propostas por empresas investigadas por danos ambientais a fim de que seja declarada a ilicitude da atividade por elas desempenhada e a ausência de risco ambiental; ação rescisória de decisão proferida em ação coletiva; ação anulatória de compromisso de ajustamento de conduta firmado por órgão público; ação cautelar incidental proposta pelo réu em ação civil pública (para, por exemplo, dar efeito suspensivo a recurso de sobreposição - especial ou extraordinário); reconvenção em ação civil pública; ações em defesa do meio ambiente contra movimento social que, a pretexto de estimular a reforma agrária pratica atos lesivos à natureza [...]" LEONEL, Ricardo de Barros. Manual do processo coletivo. 2. ed. São Paulo: Revista dos Tribunais, 2011. p. 205-206.

29 GIDI, Antonio. Rumo a um código de processo civil coletivo: a codificação das ações coletivas no Brasil. Rio de Janeiro: Forense, 2008, p. 348.

30 Sobre a experiência do Processo do Trabalho, v.g. Camilo Zufelato: "Por isso vai endossada a afirmação de que o dissídio coletivo pode ser considerado a primeira modalidade de ação coletiva prevista no ordenamento jurídico brasileiro. Mais do que isso, o dissídio coletivo é também uma forma de ação na qual se admite a atuação do ente
Sobre a conceituação de dissídio coletivo disserta Carlos Henrique Bezerra Leite:

[...] o dissídio coletivo é uma espécie de ação coletiva conferida a determinados entres coletivos, geralmente os sindicatos, para a defesa de interesses cujos titulares materiais não são pessoas individualmente consideradas, mas sim grupos ou categorias econômicas, profissionais ou diferenciadas, visando à criação ou interpretação de normas que irão incidir no âmbito dessas mesmas categorias. ${ }^{31}$

Os dissídios coletivos podem ser de natureza econômica ou jurídica. Os de natureza econômica são ações constitutivas que têm como finalidade o estabelecimento de novas condições de trabalho mediante sentença normativa. Por outro lado, os dissídios coletivos de natureza jurídica são ações declaratórias que buscam uma sentença normativa que pacifique a interpretação de certa norma jurídica, acordo ou convenção coletiva de trabalho etc. ${ }^{32}$

$\mathrm{O} \$ 2 .^{\circ}$ do art. 114 da Constituição Federal, com a redação dada pela Emenda à Constituição n. 45/2004, entre outras, traz a inusitada disposição segundo a qual o ajuizamento de um dissídio coletivo de natureza econômica depende de comum acordo entre as partes litigantes. Historicamente, para o ajuizamento de um dissídio coletivo, tal como nas outras ações, não era necessário o consenso entre as partes; nada obstante, tal situação foi alterada com a EC n. 45/2004. Tem-se notícia de que tramitam no Supremo Tribunal Federal Ações Direitas de Inconstitucionalidade nas quais se afirma que a nova redação do $\$ 2 .^{\circ}$ do art. 114 padece de inconstitucionalidade em função do princípio da inafastabilidade da jurisdição. ${ }^{33}$

Ademais, doutrina que trata do processo coletivo

coletivo em juízo como substituto processual dos interessados no polo passivo da demanda, com um provimento jurisdicional que vinculará os substituídos, tal como ocorre nas defedant class actions contemporâneas. Por tais características deve-se reconhecer o dissídio coletivo como verdadeira ação coletiva passiva brasileira, a primeira nessa natureza”. ZUFELATO, Camilo. Ação coletiva passiva no direito brasileiro: necessidade de regulamentação legal. In: GOZZOLI, Maria Clara et al. (Org.). Em defesa de um novo sistema de processos coletivos: estudos em homenagem a Ada Pellegrini Grinover. São Paulo: Saraiva, 2010, p. 89.

31 LEITE, Carlos Henrique Bezerra. Curso de direito processual do trabalho. 10. ed. São Paulo: LTr, 2012. p. 1212.

32 LEITE, Carlos Henrique Bezerra. Curso de direito processual do trabalho. 10. ed. São Paulo: LTr, 2012. p. 1213.

33 LEITE, Carlos Henrique Bezerra. Curso de direito processual do trabalho. 10. ed. São Paulo: LTr, 2012. p. 1224-1225. 
do trabalho questiona se a sentença normativa produz ou não coisa julgada. ${ }^{34}$ Esses questionamentos devem ser respondidos com base na Súmula 397 do Tribunal Superior do Trabalho, a qual tomamos a liberdade de transcrever:

Súmula $\mathrm{n}^{\circ} 397$ do TST

AÇÃO RESCISÓRIA. ART. 485, IV, DO CPC. AÇÃO DE CUMPRIMENTO. OFENSA À COISA JULGADA EMANADA DE SENTENÇA NORMATIVA MODIFICADA EM GRAU DE RECURSO. INVIABILIDADE. CABIMENTO DE MANDADO DE SEGURANÇA (conversão da Orientação Jurisprudencial n ${ }^{\circ} 116$ da SBDI-2) - Res. 137/2005, DJ 22, 23 e 24.08.2005

Não procede ação rescisória calcada em ofensa à coisa julgada perpetrada por decisão proferida em ação de cumprimento, em face de a sentença normativa, na qual se louvava, ter sido modificada em grau de recurso, porque em dissídio coletivo somente se consubstancia coisa julgada formal. Assim, os meios processuais aptos a atacarem a execução da cláusula reformada são a exceção de pré-executividade e o mandado de segurança, no caso de descumprimento do art. 572 do CPC. (ex-OJ $n^{\circ} 116$ da SBDI-2 - DJ 11.08.2003)

Pelo que se vê, a Súmula 397 do TST consagra que o dissídio coletivo produz tão somente coisa julgada formal, o que pode causar alguma perplexidade quando se leva em conta que o art. 2. ${ }^{\circ}$ I, $c$, da Lei n. 7.701/88 estabelece que o cabimento de ação rescisória de sentença normativa prolatada em dissídio coletivo. ${ }^{35}$

Quanto à abrangência da coisa julgada em um dissídio coletivo, Ronaldo Lima dos Santos a classifica como sendo ultra partes, vez que se limita às categorias envolvidas (vide o inc. III do art. 8 da Constituição Federal), porém, nesses dissídios, a formação da coisa julgada independe do resultado do processo. ${ }^{36}$ Sobre isso, afirma o referido autor:

Diferentemente das sentenças proferidas em ações civis públicas e nas ações coletivas do Código de Defesa do Consumidor, nas quais

34 LEITE, Carlos Henrique Bezerra. Curso de direito processual do trabalho. 10. ed. São Paulo: LTr, 2012. p. 1229.

35 LEITE, Carlos Henrique Bezerra. Curso de direito processual do trabalho. 10. ed. São Paulo: LTr, 2012. p. 1230.

36 SANTOS, Ronaldo Lima dos. "Defendant Class Actions". O Grupo como Legitimado Passivo no Direito Norte-Americano e no Brasil. Boletim Científico da Escola Superior do Ministério Público da União. Brasília, p. 150, jan./mar. 2004. a coisa julgada forma-se, respectivamente, secundum eventum litis e in utilibus, na hipótese de dissídio coletivo, tanto a sentença favorável quanto a desfavorável, parcial ou totalmente, à categoria fazem coisa julgada. No entanto, revela notar que, diversamente das demais ações coletivas, o dissídio coletivo, em geral, não possui natureza condenatória, salvo quanto às custas do processo, pois, como asseverado, a decisão terá natureza constitutiva ou declaratória, não havendo possibilidade de imputação de obrigação aos membros da categoria; esses, entretanto, estarão vinculados à observação do conteúdo constitutivo do declaratório da decisão proferida. ${ }^{37}$

Pelo exposto, verifica-se que a comparação feita entre os dissídios coletivos trabalhistas e a ação coletiva passiva do direito comum não pode ser superestimada. ${ }^{38} \mathrm{O}$ conjunto normativo que regula o direito coletivo do trabalho possui muitas peculiaridades que chegam a causar estranheza ao operador acostumado a lidar com processo civil coletivo.

\section{Ações coletivas passivas nos Estados Unidos}

Os autores favoráveis à admissão das ações coletivas passivas no Brasil corriqueiramente buscam referências na experiência norte-americana das defendant class actions. ${ }^{39}$ Em razão disso, objetivamos abordar os pontos centrais do processo coletivo estadunidense. De fato, como observado por Vincezo Vigoritti, o maior desenvol-

37 SANTOS, Ronaldo Lima dos. "Defendant Class Actions". O Grupo como Legitimado Passivo no Direito Norte-Americano e no Brasil. Boletim Científico da Escola Superior do Ministério Público da União, Brasília, p. 150, jan./mar 2004.

38 Talvez uma das interessantes características dos dissídios coletivos que pode ser aplicada às ações coletivas passivas do direito comum diz com a possibilidade de aplicação de astreintes em sede de obrigação de fazer a ser cumprida pela coletividade. SANTOS, Ronaldo Lima dos. "Defendant Class Actions". O Grupo como Legitimado Passivo no Direito Norte-Americano e no Brasil. Boletim Científico da Escola Superior do Ministério Público da União, Brasília, p. 150, jan./mar. 2004.

39 Sobre o assunto, merece destaque o alerta feito por Camilo Zufelato, segundo o qual [...] a previsão de longa data das defendant class actions na experiência norte-americana realmente é uma referência, mas que não poderá ser supervalorizada, visto que as class actions têm certas características incompatíveis com o modelo brasileiro, sobretudo quanto à coisa julgada. ZUFELATO, Camilo. Ação coletiva passiva no direito brasileiro: necessidade de regulamentação legal. In: GOZZOLI, Maria Clara et al. (Org.). Em defesa de um novo sistema de processos coletivos: estudos em homenagem a Ada Pellegrini Grinover. São Paulo: Saraiva, 2010. p. 114115. 
vimento do processo coletivo no ordenamento estadunidense, e nos países de common law em geral, faz com que a experiência americana das class actions seja sempre um fértil campo de estudo para os interessados no tema. ${ }^{40}$

Inicialmente, é necessário frisar que a doutrina norte-americana reconhece três tipos de ações coletivas: plaintiff class actions (o grupo encontra-se no polo ativo da demanda); defendant class actions (o grupo compõe o polo passivo) e bilateral class actions (modalidade em que existem grupos no polo ativo e no passivo da demanda). ${ }^{41}$

Para a compreensão das defendant class actions nos Estados Unidos, é imprescindível discorrer sobre alguns dos aspectos gerais atinentes ao sistema de direito processual desse país - cuja tônica indiscutivelmente são as plaintiff class actions.

Conforme destacado por Antônio Gidi, duas importantes facetas do direito processual norte-americano são o viés pragmático e a flexibilidade procedimental que garantem ao juiz um grande dirigismo sobre o procedimento, as partes, os advogados, terceiros interessados etc. Para Gidi, a sociedade estadunidense reconhece que os litígios judiciais constituem uma relevante forma de modificação do status quo, algo potencializado pela força ostentada pelos precedentes. ${ }^{42}$

A citada flexibilidade procedimental foi um dos aspectos que possibilitaram o surgimento das class actions. Este estudo não pretende proceder a uma digressão histórica acerca das origens do instituto; porém, interessa saber que hoje as class actions encontram-se reguladas pela Rule 23, que ganhou a coloração atual com a reforma de $1966 .{ }^{43}$ Em que pese os estados norte-americanos terem competência para legislar sobre normas de direito processual, no que tange às class actions, a grande maioria

40 VINCENZO, Vigoriti. Interessi colletivi e processo: la legittimazione ad agire. Milão: Giuffrè, 1979. p. 252.

${ }^{41}$ GIDI, Antonio. Rumo a um código de processo civil coletivo. A codificação das ações coletivas no Brasil. Rio de Janeiro: Forense, 2008. p. 339.

42 GIDI, Antonio. Class Actions in Brazil. A Model for Civil Law Countries. The America Journal of Comparative Law, v. 51, p. 311-408, 2003. Disponível em: <http://www.temple. edu/lawschool/iilpp/images/PDFs/GidiGidiClassActions. pdf $>$. Acesso em: 29 jul. 2012. p. 314-317.

43 FORMACIARI, Flávia Hellmeister Clito. A representatividade adequada nos processos coletivos. 2009. 189 f. Tese (Doutorado) - Programa de Pós Graduação em Direito da Universidade de São Paulo. Disponível em: <www.teses. usp.br/.../Representatividade_Adequada_nos_Processos Coletivos.pdf>. Acesso em: 29 jul. 2012. p. 37. dos estados segue as regras estabelecidas na Rule 23 das Federal Rules of Civil Procedure. ${ }^{44}$

Os requisitos das class actions estão previstos na alínea (a) da Rule 23; sobre eles assevera Flávia Hellmeister Clito Formaciari:

[...] uma ação só poderá ser tida como coletiva se preenchidos todos os requisitos especificados na Rule 23 (a), quais sejam, numerosidade excessiva, que impede a formação de um litisconsórcio (1), existência de questões de fato ou de direito comuns (2), tipicidade dos pedidos em relação aos membros do grupo (3) e representatividade adequada em juízo (4). O ônus de demonstrar a presença desses requisitos, ou, ao menos, de trazer prova razoável quanto a eles, é do autor da demanda, em fase prévia, existente tão só para auferi-los, na determinada fase de certificação. ${ }^{45}$

Importa destacar que as class actions impreterivelmente devem passar por uma fase de certificação, quando a corte decidirá se a classe será "dissolvida" ou "certificada" - nessa hipótese a demanda prosseguirá. ${ }^{46}$

Conforme destaca Nelson Rodrigues Netto, qualquer class action, seja ela ativa, passiva ou bilateral deve atender aos requisitos elencados na Rule $23(a) .{ }^{47}$

Já as hipóteses de cabimento das class actions encontram-se na alínea (b), sobre elas preconiza Formaciari:

[...] após o preenchimento dos requisitos no item (a) da Rule 23, deve a demanda coletiva enquadrar-se numa das hipóteses de cabimento trazidas em seu item (b), quais sejam, risco de conflito de decisões (1), conduta uniforme do réu (2) e predominância das questões comuns (3). ${ }^{48}$

Ao se estudar as hipóteses de cabimento previstas na Rule 23 (b), deve-se atentar ao fato de que os concei-

44 MENDES, Aluisio Gonçalves de Castro. Ações coletivas no direito comparado e nacional. São Paulo: Revista dos Tribunais, 2002. p. 73.

45 FORMACIARI, Flávia Hellmeister Clito. A representatividade adequada nos processos coletivos. 2009. 189 f. Tese (Doutorado) - Programa de Pós Graduação em Direito da Universidade de São Paulo. Disponível em: <www.teses. usp.br/.../Representatividade_Adequada_nos_Processos_ Coletivos.pdf $>$. Acesso em: 29 jul. 2012. p. 38.

46 GRINOVER, Ada Pellegrini; WATANABE, Kazuo; MULLENIX, Linda. Os processos coletivos nos países de civil Law e common law: uma análise de direito comparado. 2. ed. São Paulo: Revista dos Tribunais, 2011. p. 272.

47 NETTO, Nelson Rodrigues. Subsídios para a Ação Coletiva Passiva Brasileira. Revista de Processo, v. 149, p. 79-104, 2007. p. 98.

48 NETTO, Nelson Rodrigues. Subsídios para a ação coletiva passiva brasileira. Revista de Processo, v. 149, p. 79-104, 2007. p. 98. 
tos de interesses difusos, coletivos e individuais e homogêneos, tal como conhecemos, não são utilizados nos ordenamentos de common law. Existe posicionamento no sentido de que, com as devidas ressalvas, seria possível estabelecer um paralelo entre as duas primeiras categorias de class actions reguladas pelo item (b) da Rule $23 \mathrm{e}$ a tutela dos interesses difusos e coletivos nos sistemas de civil law. Já as ações reguladas pela Rule 23(b)(3) guardariam semelhança com as ações brasileiras destinadas à tutela de interesses individuais e homogêneos. ${ }^{49}$ Porém, em que pese a comparação citada, parece prudente evitá-la, mormente em face dos ensinamentos de Antônio Gidi, para quem tais conceitos - teorizações elaboradas pela doutrina italiana e positivadas na legislação coletiva brasileira — não são adotados pelo ordenamento norte-americano, que não trabalha com categorias abstratas de direitos ou interesses. ${ }^{50}$

Sem a pretensão de maior aprofundamento no assunto, pode-se dizer que as ações previstas nas alíneas (b) (1) e (b)(2) da Rule 23, conhecidas como mandatory class actions, não permitem que um membro da classe exerça o direito de autoexclusão - diferentemente do que ocorre nas ações previstas na Rule 23 (b)(3) - non mandatory class actions. ${ }^{51}$ Sinteticamente, os critérios utilizados para a definição das hipóteses de cabimento das class actions são os seguintes: possibilidade decisões conflitantes em face de membros do mesmo grupo - Rule 23(b)(1)(a); possibilidade que decisões proferidas em processos individuais prejudiquem outros membros da classe - Rule $23(b)(1)(b)$; negativa da parte ré em agir uniformemente com relação a determinado grupo, de acordo com um dever legal - Rule 23(b)(2); e, finalmente, quando, de acordo com o entendimento do juiz, existência de questões comuns aos membros da classe que sejam superiores em face de questões individuais - Rule 23(b)(3). ${ }^{52}$

Segundo Antonio Gidi, hodiernamente as ações

49 GRINOVER, Ada Pellegrini; WATANABE, Kazuo; MULLENIX, Linda. Os processos coletivos nos países de civil lawe common law: uma análise de direito comparado. 2. ed. São Paulo: Revista dos Tribunais, 2011. p. 267.

50 GIDI, Antonio. A Class Action como instrumento de tutela coletiva dos direitos. São Paulo: Revista dos Tribunais, 2007. p. 141.

51 GIDI, Antonio. A Class Action como instrumento de tutela coletiva dos direitos. São Paulo: Revista dos Tribunais, 2007. p. 143.

52 GIDI, Antonio. A Class Action como instrumento de tutela coletiva dos direitos. São Paulo: Revista dos Tribunais, 2007. p. 161. previstas na alínea (b)(1) são as menos utilizadas na prática; já as da alínea (b)(2) tiveram seu auge na efervescente luta pelos direitos civis nas décadas de 1960 e $1970 .^{53}$ Atualmente, as class actions governadas pela Rule 23(b) (3) são as mais comuns, uma vez que se prestam à tutela de pequenas causas com fato gerador comum e que seriam inviáveis se propostas de forma individual. ${ }^{54} 55$

Sobre as outras alíneas, subdivisões, da Rule 23, sinteticamente pontua Rodrigues Netto:

A subdivisão 23 (c) disciplina o momento e os elementos para a decisão de certificação da classe, a conveniência da intimação e seu conteúdo; e, os efeitos do julgamento; a subdivisão 23 (d) concerne às ordens na condução dos processos; a subdivisão 23 (e) é relativa à transação, à desistência e ao compromisso; a subdivisão 23 (f) lida com os recursos; a subdivisão 23 (g) disciplina o advogado da classe, e, finalmente, a subdivisão 23 (h) trata da concessão de honorários advocatícios. ${ }^{56}$

Dentre os requisitos das class actions merece especial destaque a representatividade adequada (adequacy of representation), prevista na Rule 23 (a)(4). As class actions são ações representativas, logo, cabe a um representante da classe representar em juízo os membros ausentes. A adequação da representatividade será auferida pela Corte antes que a classe seja certificada, ademais, a ausência de

53 GIDI, Antonio. A Class Action como instrumento de tutela coletiva dos direitos. São Paulo: Revista dos Tribunais, 2007. p. 142.

54 GRINOVER, Ada Pellegrini; WATANABE, Kazuo; MULLENIX, Linda. Os processos coletivos nos países de civil lawe common law: uma análise de direito comparado. 2. ed. São Paulo: Revista dos Tribunais, 2011. p. 268.

55 Uma corriqueira preocupação por parte da doutrina norte-americana que trata das class actions diz com os incentivos dados ao advogado para a propositura de uma ação. Nessa linha, cita-se Owen Fiss ao discorrer sobre o processo civil em seu país: [...] nos Estados Unidos, operarmos sob uma norma que não concede os honorários advocatícios ao vencedor, não há um prêmio em específico para a cobertura de despesas advocatícias, e isto significa que o pagamento do advogado do autor da ação deve ser subtraído da indenização que este recebe do réu, caso haja êxito. Quando a indenização pelo prejuizo é de sessenta milhões de dólares, há mais do que o suficiente para ser divido; haveria um exército de advogados preparados para promover essa ação, os quais veriam motivação para tanto no valor dos honorários advocatícios devidos em caso de sucesso, o que não acontece quando a indenização é de setenta dólares. FISS, Owen. Um novo processo civil: estudos norte-americanos sobre jurisdição, constituição e sociedade. São Paulo: Revista dos Tribunais, 2004. p.236-237.

56 NETTO, Nelson Rodrigues. Subsídios para a ação coletiva passiva brasileira. Revista de Processo, v. 149, p. 79-104, 2007. p. 92. 
representatividade adequada pode ser declarada a qualquer momento do processo. ${ }^{57}$

Sobre a representatividade adequada, é oportuno destacar que, em se tratando de class actions, ela deve ser auferida tanto quanto relação ao representante da classe na relação jurídica processual como com relação aos seus advogados. No que toca ao representante da classe - que deve ser um membro dela - Aluísio de Castro Mendes destaca alguns aspectos necessários, tais como “[...] o comprometimento com a causa, a motivação e o vigor na condução do feito, o interesse em jogo, as disponibilidades de tempo e a capacidade financeira [...]" ${ }^{58}$; já com relação ao advogado, segundo Mendes, importa averiguar, entre outras características [...] "a especialização profissional na área, a experiência com ações coletivas, a qualidade dos escritos submetidos ao tribunal e "performance" na causa como um todo" [...]. ${ }^{59}$

Por fim, deve ser dito que procedência ou improcedência de uma class action ensejará a preclusão futuras de ações propostas por outros legitimados. Owen Fiss atesta que o fato de a coisa julgada nas demandas coletivas atingir indistintamente todos os membros da classe não encontra explicações suficientemente sólidas, contudo, segundo o autor, talvez a principal razão disso resida na necessária simetria dos riscos da demanda, tanto para o autor quanto para o réu. ${ }^{60}$ Frise-se que a amplitude subjetiva da coisa julgada nas class actions é potencializada pelo instituto da representatividade adequada, que assegura um contraditório de qualidade apesar de nem todos os membros da classe estarem presentes no processo.

Sobre as defendant class actions, Francis Xavier Shen (professor da Universidade Minessota), em artigo intitulado The overlooked utility of the defendant class action, afirma que essas ações são pouco estudadas nas universidades americanas e subutilizadas na prática. ${ }^{61} \mathrm{O}$

57 GRINOVER, Ada Pellegrini; WATANABE, Kazuo; MULLENIX, Linda. Os processos coletivos nos países de civil lawe common law: uma análise de direito comparado. 2. ed. São Paulo: Revista dos Tribunais, 2011. p.282.

58 MENDES, Aluisio Gonçalves de Castro. Ações coletivas no direito comparado e nacional. São Paulo: Revista dos Tribunais, 2002. p. 82.

59 MENDES, Aluisio Gonçalves de Castro. Ações coletivas no direito comparado e nacional. São Paulo: Revista dos Tribunais, 2002. p. 82.

60 FISS, Owen. Um novo processo civil: estudos norte-americanos sobre jurisdição, constituição e sociedade. São Paulo: Revista dos Tribunais, 2004. p. 239-240. autor destaca que as defedant class actions propostas no país comumente esbarram nas regras de certificação que são mais facilmente atendidas em causas que versem sobre infração de patentes, validade de leis locais e questões relativas a seguros.

Antonio Gidi pontua que as defedant class actions podem ser utilizadas com vistas a atribuir eficácia erga ommes a uma decisão com carga declaratória ou injuntiva em que o polo passivo é composto por um grupo de pessoas que cometeram ilícito civil. Nesse caso, a condenação do grupo ao pagamento de uma indenização depende da formulação de defesas individualizadas. Gidi também lembra que as defendant class actions podem ser manejadas de forma a interpretar ou determinar a validade de um ato normativo. ${ }^{62}$

Em que pese a Rule 23 admitir as defendant class actions (conforme a Rule 23(a): One or more members of class may sue or be sued as representative parties on behalf of the class), tal diploma não faz menção aos requisitos, ao procedimento ou às hipóteses de cabimento desse tipo de class action. Rotineiramente as disposições estabelecidas na Rule 23, elaboradas com vistas a regrar primordialmente as plaintiff class actions, devem ser adequadas às ações coletivas passivas. ${ }^{63}$

É possível que uma defendant class action seja certificada com fundamento em qualquer uma das hipóteses previstas na Rule 23 (b). ${ }^{64}$

Segundo Shen, a certificação da classe ré é mais simples quando as relações entre membros e classe estão claramente demarcadas. Existem casos em que a representatividade adequada é virtualmente garantida, principalmente quando existe uma liderança identificável ou vínculo legal entre os membros da classe. ${ }^{65}$

fendant Class Action.Denver. University Law Review, v. 88, p.73-181, 2010. Disponível em: <http://www.law.du.edu/ documents/denver-university-law-review/v88-1/Shen_FinalProof 21111.pdf>. Acesso em: 29 jul. 2012. p. 77-78.

62 GIDI, Antonio. A Class Action como instrumento de tutela coletiva dos direitos. São Paulo: Revista dos Tribunais, 2007. p. 390.

63 GIDI, Antonio. A Class Action como instrumento de tutela coletiva dos direitos. São Paulo: Revista dos Tribunais, 2007. p. 393.

64 NETTO, Nelson Rodrigues. Subsídios para a ação coletiva passiva brasileira. Revista de Processo, v. 149, p. 79-104, 2007. p. 99.

65 SHEN, Francis Xavier. The Overlooked Utility of the Defendant Class Action. Denver University Law Review, v. 88, p.73-181, 2010. Disponível em: <http://www.law.du.edu/ documents/denver-university-law-review/v88-1/Shen_Fi- 
Nessa linha, Rodrigues Netto trata da teoria do link jurídico, para essa teoria, existindo uma ligação jurídica entre os réus, faz-se necessária uma solução única para todos os demandados, o que é viabilizado pela defendant class action. O referido autor ressalta ainda que as defendant class actions apresentam questões peculiares no que toca à eleição do representante adequado, mormente, pois tal indicação é feita pelo autor da ação, o que abre espaço para a escolha de um membro da classe com poucas possibilidades de formular uma defesa sólida. Não obstante, a adequação do representante pode ser questionada pelos membros da classe. Além disso, é fundamental que as defesas apresentadas pelo representante sejam comuns à classe como um todo. Uma defesa será atípica quando pertinente somente ao representante da classe, destarte, inapta a resguardar os interesses dos membros ausentes. ${ }^{66}$

Mas a questão da representatividade adequada nas defendant class actions é ainda mais problemática. Como destacado por Gidi, em geral o representante de uma defendat class não tem interesse em representar a classe em juízo uma vez que deverá arcar com os altos custos da demanda coletiva. Nessa linha, por vezes os representantes valem-se do argumento de que, como não estão dispostos a representar o grupo, não seriam representantes adequados (unwilling class representatives) - argumento veementemente rechaçado pela jurisprudência, que, no leading case Macera v. Chilund consagrou o entendimento de que a adequação do representante independe de sua voluntariedade. ${ }^{67}$

As peculiaridades do processo civil norte-americano fazem com que a capacidade financeira do representante assuma fulcral importância em se tratando de defendant class action. Como dito, o representante poderá ter que custear sozinho as elevadas despesas do processo, mormente com relação à produção de provas e honorários advocatícios. Logo, com vistas a mitigar essa indesejável situação, pode o juiz determinar a inclusão de outros integrantes da classe no polo passivo, como litisconsortes, de forma a repartir o ônus financeiro. ${ }^{68}$

nalProof_21111.pdf>. Acesso em: 29 jul. 2012. p. 85.

66 NETTO, Nelson Rodrigues. Subsídios para a ação coletiva passiva brasileira. Revista de Processo, v. 149, p. 95-97, 2007.

67 GIDI, Antonio. A Class Action como instrumento de tutela coletiva dos direitos. São Paulo: Revista dos Tribunais, 2007. p. 407.

68 GIDI, Antonio. A Class Action como instrumento de tutela coletiva dos direitos. São Paulo: Revista dos Tribunais, 2007. p. 409-410.

\section{Definições de ação coletiva passiva}

Retornando ao direito nacional, passamos a expor algumas das definições de ação coletiva passiva cunhadas pela doutrina brasileira.

Ada Pellegrini Grinover chama de ação coletiva passiva “[...] a ação promovida não pelo grupo, mas contra o grupo, correspondendo à defendant class action do sistema norte-americano [...]." A festejada processualista lembra ainda que mesmo nos países que as admitem, as ações coletivas passivas são muito mais raras que as ativas. ${ }^{69}$

Por sua vez, Ricardo de Barros Leonel destaca o fato de a coletividade estar no polo passivo da demanda, seja em uma ação proposta por um particular, seja em uma ação proposta por outro grupo - situação em que se teria uma coletividade litigando contra outra, o que o autor denomina de conflito essencialmente coletivo. ${ }^{70}$

Fredie Didier JR. e Hermes Zaneti JR. dizem haver uma ação coletiva passiva "[...] quando um agrupamento humano for colocado como sujeito passivo de uma relação jurídica afirmada na petição inicial." ${ }^{\text {"1 }}$ Os referidos processualistas asseveram ainda que uma ação coletiva passiva pode veicular pretensões individuais ou coletivas. Estabelecem que uma coletividade, além de ser titular de direitos, também possui deveres. Diante disso, os autores preconizam ser necessário o desenvolvimento do conceito de situação jurídica coletiva passiva. ${ }^{72}$

Já Camilo Zufelato propõe três parâmetros essenciais às ações coletivas passivas, são eles: $a$ ) a concessão de legitimidade passiva à coletividade; $b$ ) o necessário vínculo entre os indivíduos representados no polo passivo da demanda; $c$ ) a tutela de direitos transindividuais, o autor não uma ação coletiva passiva possa ser proposta para defender direitos individuais. ${ }^{73}$

69 GRINOVER, Ada Pellegrini; WATANABE, Kazuo; MULLENIX, Linda. Os processos coletivos nos países de civil lawe common law: uma análise de direito comparado. 2. ed. São Paulo: Revista dos Tribunais, 2011. p. 236.

70 LEONEL, Ricardo de Barros. Manual do processo coletivo. 2. ed. São Paulo: Revista dos Tribunais, 2011. v. 1, p. 205-202.

71 DIDIER JUNIOR., Fredie; ZANETI JUNIOR., Hermes. Curso de direito processual civil: processo coletivo. 4. ed. Salvador: Jus Podivm, 2009. p .411.

72 DIDIER JUNIOR., Fredie; ZANETI JUNIOR., Hermes. Curso de direito processual civil: processo coletivo. 4. ed. Salvador: Jus Podivm, 2009. p. 412-413.

73 ZUFELATO, C. Ação coletiva passiva no direito brasileiro: necessidade de regulamentação legal. In: GOZZOLI, Maria 
Em dissertação de mestrado destinada ao assunto, Diogo Campos Medina Maia define a ação coletiva passiva no direito brasileiro como:

[...] o direito apto a ser legitima e autonomamente exercido, de modo ordinário ou extraordinário, por pessoas naturais, jurídicas ou formais, em face de um ente coletivo com legitimidade extraordinária, conforme possibilidade inferida do ordenamento jurídico, a fim de exigir a prestação jurisdicional, com o objetivo de tutelar interesses ou direitos homogeneamente lesionados, ou ameaçados de lesão, independente de seu caráter individual ou coletivo. ${ }^{74}$

Entendemos que a citada passagem tem o mérito de introduzir a noção de direitos individuais homogeneamente lesionados. Ora, no contexto da sociedade de massas, um direito individual, ou ainda um direito coletivo, pode sofrer inúmeras e até mesmo incontáveis lesões ou ameaças de lesão semelhantes — v.g., um direito autoral violado por inúmeros downloads ilegais ${ }^{75}$ ou mesmo o patrimônio histórico de Diamantina, no caso concreto citado neste trabalho, foi ameaçado de lesão pelos inúmeros estudantes que ocupavam durante o carnaval as repúblicas instaladas em prédios históricos.

Em uma analise crítica das definições trazidas, primeiramente, verifica-se, que a expediência das defendant class actions norte-americanas realmente é um fecundo objeto de estudo para quem se interessa pelas ações coletivas passivas; conduto, existem sensíveis diferenças entre o processo civil coletivo estadunidense e o brasileiro. Muitas das hipóteses que, em tese, podem dar azo a uma ação coletiva passiva no Brasil não encontram paralelo na prática norte-americana ${ }^{76}$ - e vice-versa. Des-

Clara et al. (Org.). Em defesa de um novo sistema de processos coletivos: estudos em homenagem a Ada Pellegrini Grinover. São Paulo: Saraiva, 2010. v. 1. p. 92.

74 MAIA, Diogo Campos Medina. Ação Coletiva Passiva. Rio de Janeiro: Lumen Juris, 2009. p.53.

75 Ao discorrer sobre a casuística norte-americana, Nelson Rodrigues Netto faz menção ao caso MGM V. Grokster, no qual figuraram como autores da demanda um grupo de estúdios musicais e alguns detentores de direitos autores e, no polo passivo, encontravam-se companhias que distribuíam programas gratuitos que permitem que usuários compartilhem arquivos pelo sistema peer-to-peer. O caso foi registrado como sendo uma bileteral class action (ação em que existe uma coletividade tanto no polo ativo, quanto no polo passivo). NETTO, Nelson Rodrigues. The Use of Defendant Class Actions to Protect Rights in the Internet. Panóptica, Vitória, v. 1, p. 3, 2007. p. 61.

76 De acordo com Francis X. Shen, nos Estados Unidos as defedant class actions propostas em sua grande maioria versam sobre a constitucionalidade de determinada lei, se- tarte, o paralelo traçado entre a ação coletiva passiva e a defendant class action pode ser interessante ao menos em uma introdução ao tema.

As definições de Ricardo de Barros Leonel, Fredie Didier Junior. e Hermes Zaneti Junior. têm o mérito de mostrar que a ação coletiva pode servir à tutela de direitos individuais, coletivos, difusos ou individuais homogêneos. Ao passo que o microssistema de processo coletivo brasileiro admite que direitos individuais e homogêneos, coletivos, ou difusos litiguem (no polo ativo) contra um legitimando passivo ordinário, poder-se-ia imaginar situações em que um direito individual (no polo ativo) tenha sido violado ou ameaçado de lesão de forma coletiva, difusa ou de forma individual e homogênea. Dando sequência ao raciocínio, poder-se-ia imaginar a possibilidade de direitos coletivos litigando entre si, de direitos individuais e homogêneos estarem no polo ativo e no polo passivo estarem, nas palavras de Didier, deveres ou estados de sujeição indivisíveis (difusos ou coletivos) ${ }^{77}$, além de uma série de outras combinações possíveis.

Porém, focando no pensamento de Didier, parece ser complicado imaginar uma ação coletiva passiva seja proposta contra deveres e estados de sujeição difusos tal categoria, quiçá, possa ser materializada em uma ação rescisória de ação coletiva ativa na qual se obteve sentença de procedência para tutela de determinado direito difuso. Quanto às outras hipóteses, Didier cunhou os seguintes exemplos:

Um direito coletivo pode estar correlacionado a uma situação passiva individual (p. ex: o direito coletivo de exigir que uma determinada empresa proceda à correção de sua publicidade). Um direito individual pode estar relacionado a uma situação jurídica passiva coletiva (p. ex.: o direito do titular de uma patente impedir a sua reiterada violação por um grupo de empresas). Um

guros, damages (ações similares às usadas para tutela dos direitos individuais e homogêneos no Brasil), direitos de propriedade, questões previdenciárias, anti-trust, patentes etc. SHEN, Francis Xavier. The Overlooked Utility of the Defendant Class Action. Denver University Law Review, v. 88, p.73-181, 2010. Disponível em: <http://www.law.du.edu/ documents/denver-university-law-review/v88-1/Shen_FinalProof_21111.pdf>. Acesso em: 29 jul. 2012. p. 83.

77 DIDIER, Fredie. Situações jurídicas coletivas passivas: o objeto das ações coletivas passivas. Revista Eletrônica de Direito do Estado (REDE), Salvador, Instituto Brasileiro de Direito Público, n. 26, abr./jun. 2011. Disponível em:_ <http://www.direitodoestado.com/revista/REDE-26-ABRIL-2011-FREDDIE-DIDIER.pdf>. Acesso em: 9 maio 2013. p . 2. 
direito coletivo pode estar relacionado, finalmente, a uma situação jurídica coletiva (p.ex.: o direito de uma categoria de trabalhadores a que determinada categoria de empregadores reajuste o salário-base). ${ }^{78}$

Nessa linha de raciocínio, considerável parcela da doutrina favorável às ações coletivas passivas no direito brasileiro, ao elencar exemplos de processos coletivos passivos, vislumbra a possibilidade de um autor individual, potencial réu em uma ação coletiva ativa, veicular uma pretensão declaratória em ação coletiva passiva. Quanto a isso, Ricardo de Barros Leonel cita a possibilidade de uma empresa investigada por crimes ambientais propor uma ação coletiva passiva para que seja declarada a licitude de suas atividades ${ }^{79}$ (uma ação coletiva passiva proposta contra deveres e estados de sujeição difusos); cogitou-se até que determinada operadora de cartões de crédito obtivesse a declaração da licitude de cláusulas de contrato de adesão. ${ }^{80}$ Quanto ao último exemplo, não custa lembrar que o enunciado n. ${ }^{\circ} 181$ da súmula do Superior Tribunal de Justiça tem a seguinte redação: "É admissível ação declaratória, visando a obter certeza quanto à exata interpretação de cláusula contratual." Destarte, é inquestionável que transposição desse entendimento à seara das ações coletivas passivas causa alguma perplexidade.

Curiosamente, há muitos anos, Vincenzo Vigoriti - ao imaginar a possibilidade de uma ação proposta contra um interesse coletivo - cogitou exemplo semelhante aos supracitados:

\begin{abstract}
In astratto, tuttavia, l'ipotesi di un'azine diretta contro i contitolari di un certo interesse superindividuale non può essere aprioristicamente esclusa. Si potrebbero, ad esempio, configurare azioni di mero accertamento (positivo o negativo) promosse da un imprenditore, o da altri soggetti comunque interessi, e dirette ad eliminare incertezze sulla legittimità e sull' adeguatezza di impianti di depurazione, sulla sufficienza dei mezzi adottati per tutelare la salute dei membri di una certa comunità, o di un'impresa, ecc. Lo
\end{abstract}

78 DIDIER, Fredie. Situações jurídicas coletivas passivas: o objeto das ações coletivas passivas. Revista Eletrônica de Direito do Estado (REDE), Salvador, Instituto Brasileiro de Direito Público, n. 26, abr./jun. 2011. Disponível em: <http://www.direitodoestado.com/revista/REDE-26-ABRIL-2011-FREDDIE-DIDIER.pdf $>$. Acesso em: 9 maio 2013. p. 2.

79 LEONEL, Ricardo de Barros. Manual do processo coletivo. 2. ed. São Paulo: Revista dos Tribunais, 2011. p. 205.

80 TOZZI, Thiago Oliveira. Ação Coletiva Passiva: conceito, características e classificação. Revista de Processo, v. 205, p. 267-296, 2012. p. 273. spazio per ipotesi di questo tipo (o di altro tipo) è ovviamente assai ridotto, ma è difficili negarlo del tutto. ${ }^{81}$

Os argumentos favoráveis a esse tipo de ação circundam em torno economia processual, da necessidade de se eliminar uma situação de incerteza e no fato de que a improcedência de uma ação coletiva ativa resulta na negação do direito afirmado pelo autor. ${ }^{82} \mathrm{Em}$ se admitindo essa possibilidade, inexoravelmente associações habituadas à defesa de interesses coletivos, tais como as associações ambientais ou de defesa do consumidor, frequentemente seriam rés em processos coletivos passivos.

Porém, em sentido inverso, despontam os fortes argumentos de Antônio Gidi, segundo o qual esses exemplos teriam com ponto de partida a errônea concepção de que a ação coletiva passiva é uma ação coletiva ativa invertida. $\mathrm{O}$ autor chama essas demandas de ações coletivas propostas por emboscada, uma vez que, de maneira abusiva, buscam antecipar uma ação coletiva ativa, de forma a atingir um grupo que ainda não estaria preparado para manejar um processo de tal magnitude. ${ }^{83}$ Nas palavras de Gidi: "[...] não cabe ao réu antecipar-se ao grupo, para tentar obter a "paz global" e tentar "matar" a futura controvérsia em seu nascendo." ${ }^{84}$

Fredie Didier Jr. e Hermes Zaneti Jr. também repudiam esse potencial uso da ação coletiva passiva, uma vez que não prestigia o interesse público. Porém, como ensinam esses autores, isso não significa dizer que não possam existir ações coletivas passivas declaratórias. ${ }^{85}$ Por exemplo, no contexto da greve das universidades federais, o Superior Tribunal de Justiça foi chamado a decidir a Ação de Dissídio Nacional de Greve n. ${ }^{\circ}$ 0172698-40-2011.3.00.0000 ${ }^{86}$, cujo polo ativo foi composto pela Universidade Federal do Amazonas e por outras trinta e cinco universidades federais; no polo

81 VINCENZO, Vigoriti. Interessi colletivi e processo: la legittimazione ad agire. Milão: Giuffrè, 1979. p. 101.

82 LEONEL, Ricardo de Barros. Manual do Processo Coletivo. 2. ed. São Paulo: Revista dos Tribunais, 2011.p. 208.

83 GIDI, Antonio. Rumo a um código de processo civil coletivo: a codificação das ações coletivas no Brasil. Rio de Janeiro: Forense, 2008. p. 353.

84 GIDI, Antonio. Rumo a um código de processo civil coletivo: a codificação das ações coletivas no Brasil. Rio de Janeiro: Forense, 2008. p. 354.

85 DIDIER JUNIOR, Fredie ; ZANETI JUNIOR, Hermes. Curso de direito processual civil: processo coletivo. 4. ed. Salvador: Jus Podivm, 2009. p. 405-406.

86 BRASIL. Superior Tribunal de Justiça; PET 8.635/DF. Relator Ministro Arnaldo Esteves Lima. Julgado 28/06/2012. Publicado no DJ de 28/08/2012. 
passivo estavam a Federação dos Sindicatos dos Trabalhadores das Universidades Públicas Brasileiras (FASUBRA) e outras trinta e uma entidades representantes dos grevistas. Nessa ação buscou-se a declaração da ilegalidade e abusividade do movimento grevista dos servidores membros das entidades sindicais.

O último exemplo citado pode ser tido como uma autêntica ação coletiva passiva na medida em que agrupamentos humanos representados por associações de classe formaram o polo passivo da demanda.

Quanto a Camilo Zufelato, verifica-se que esse autor não cogita que uma ação coletiva passiva possa tutelar direitos individuais. Em seus escritos sobre o assunto o autor seque faz menção a essa possibilidade. ${ }^{87}$ Nesse aspecto é interessante ressaltar que o Anteprojeto de Código Brasileiro de Processos Coletivos do programa de pós-graduação da USP, amplamente discutido no Instituto Brasileiro de Direito Processual (IBDP) e posteriormente enviado ao Ministério da Justiça ${ }^{88}$, em seu art. 38, previa a possibilidade de que qualquer ação pudesse ser proposta contra uma coletividade organizada, com o ou sem personalidade jurídica, conquanto estivesse adequadamente representada. Mas, o referido anteprojeto, em seu art. $4^{\circ}$ e respectivos incisos, definia que a coletividade da demanda decorreria dos direitos ou interesses que por ela são tutelados, quais sejam: difusos, coletivos, individuais e homogêneos. Pelo exposto, podemos concluir que, caso o anteprojeto fosse promulgado, ações em que um direito não coletivo fosse contraposto a um interesse coletivo não estariam reguladas. Possivelmente essa opção decorre da inicial perplexidade causada pelo fato de um direito individual estar no polo ativo e um interesse meta-individual no passivo.

Registre-se que Zufelato propõe ainda que uma ação coletiva passiva só será viável quando existir alguma espécie de vínculo entre os integrantes do polo passivo. ${ }^{89}$

87 Conforme Zufelato, quanto à legitimidade coletiva passiva, esta pode ser entendida como sendo a aptidão de uma coletividade que congregue sujeitos de direito de ser demandada judicialmente na qualidade de grupo, categoria ou classe, como base em suposta violação de interesse difuso, coletivo "stricto sensu" - e, talvez, de interesse individual. ZUFELATO, Camilo. Ação coletiva passiva no direito brasileiro: necessidade de regulamentação legal. In: GOZZOLI, Maria Clara. Em defesa de um novo sistema de processos coletivos: estudos em homenagem a Ada Pellegrini Grinover. São Paulo: Saraiva, 2010. v. 1, p. 92.

88 ROSSI, Júlio César . A Ação Coletiva Passiva. Revista de Processo, v. 198, p. 259-280, 2011. p. 260-261.

89 ZUFELATO, Camilo. Ação coletiva passiva no direito bra-

\section{Classificação das Ações Coletivas Passivas}

A doutrina que sobre o tema das ações coletivas passivas enquadrou essas ações em algumas classificações. Inegavelmente, muitas das classificações criadas no âmbito da ciência do direito são desprovidas de qualquer utilidade. Porém, entendemos que as classificações sobre as quais discorreremos adiante podem ter alguma utilidade prática ou teórica, podendo facilitar a compreensão do fenômeno das ações coletivas passivas.

A primeira das classificações diferencia as ações coletivas passivas originárias das derivadas. Em apertada síntese, as ações coletivas passivas originárias são ações originariamente propostas contra uma coletividade não guardam qualquer relação com outra ação anterior. Já as ações coletivas passivas derivadas, nas palavras de Diogo Campos Medina Maia, são aquelas ações que, muito embora autônomas, justificam-se pela existência de uma ação coletiva ativa..$^{90}$ Como exemplos de ações passivas derivadas despontam as ações rescisórias de ação coletiva — já exemplificadas nesse artigo mediante casos concretos.

Essa classificação mostra-se útil, pois, conforme Fredie Didier Jr. e Hermes Zaneti Jr., em sede de ação coletiva passiva derivada, dificilmente surgirão problemas quanto à definição do ente coletivo represente da classe ré, já que em regra este será aquele que tiver postulado em juízo na ação coletiva ativa originária. ${ }^{91}$

Fala-se também na classificação que toma por base os interesses que se encontram contrapostos na relação jurídica processual. A expressão ação duplamente coletiva é usada para fazer referência às ações nas quais de ambos os lados existam interesses metaindividuais. ${ }^{92}$ Nesse aspecto, para aqueles que só admitem que interesses metaindividuais possam ser tutelados pela via da ação coletiva passiva, inexoravelmente todas as ações coletivas

sileiro: necessidade de regulamentação legal. In: GOZZOLI, Maria Clara et al. (Org.). Em defesa de um novo sistema de processos coletivos: estudos em homenagem a Ada Pellegrini Grinover. São Paulo: Saraiva, 2010. v. 1, p. 92.

90 MAIA, Diogo Campos Medina. Ação coletiva passiva. Rio de Janeiro: Lumen Juris, 2009. p. 122.

91 DIDIER JUNIOR, Fredie; ZANETI JUNIOR., Hermes. Curso de direito processual civil: processo coletivo. 4. ed. Salvador: Jus Podivm, 2009. p. 402.

92 TOZZI, Thiago Oliveira. Ação Coletiva Passiva: conceito, características e classificação. Revista de Processo, v. 205, p. 267-296, 2012. p. 292. 
passivas seriam ações duplamente coletivas. ${ }^{93}$ Possivelmente tal posição decorre da inicial perplexidade causada pelo fato de um direito individual estar no polo ativo e um interesse metaindividual no passivo.

Porém, entendemos que essa possibilidade não pode ser em absoluto excluída, mormente face às ações possessórias propostas contra coletividade indeterminadas ou mesmo diante da existência de ações coletivas passivas derivadas. Tomando por base um exemplo do direito norte-americano, pode-se cogitar uma ação coletiva passiva proposta pelo detentor de uma patente violada contra todos aqueles que a desrespeitaram. ${ }^{94}$

Também trazemos a este trabalho parcela do pensamento do professor norte-americano Francis Xavier Shen que, ao estudar as defendant class actions, cunhou a seguinte classificação quanto ao grau de identificação das contribuições dos membros do grupo réu para determinado evento danoso ${ }^{95}$ :

\begin{tabular}{|c|c|c|c|c|c|}
\hline Perfect ID & Stong ID & $\begin{array}{l}\text { Mid-Strong } \\
\text { ID }\end{array}$ & $\begin{array}{c}\text { Mid-Weak } \\
\text { ID }\end{array}$ & Weak ID & No ID \\
\hline $\begin{array}{l}\text { Know who } \\
\text { caused the } \\
\text { harm and } \\
\text { each party's } \\
\text { marginal } \\
\text { contributions }\end{array}$ & $\begin{array}{l}\text { Know who } \\
\text { caused the } \\
\text { harm, a little } \\
\text { less sure of } \\
\text { marginal } \\
\text { contributions }\end{array}$ & $\begin{array}{l}\text { Not entirely } \\
\text { sure who } \\
\text { caused harm, } \\
\text { but can } \\
\text { narrow it } \\
\text { down, and can } \\
\text { do the same } \\
\text { for marginal } \\
\text { contribuitions }\end{array}$ & $\begin{array}{l}\text { Know the } \\
\text { general "group" } \\
\text { of people } \\
\text { who caused } \\
\text { the harm, but } \\
\text { not specific } \\
\text { individuals in } \\
\text { the "group" and } \\
\text { know nothing } \\
\text { of marginal } \\
\text { contributions }\end{array}$ & $\begin{array}{l}\text { Not entirely } \\
\text { sure which } \\
\text { "groups" are } \\
\text { responsible, and } \\
\text { have no ideia } \\
\text { of marginal } \\
\text { contributions }\end{array}$ & $\begin{array}{c}\text { Do not } \\
\text { know who } \\
\text { caused the } \\
\text { harm }\end{array}$ \\
\hline
\end{tabular}

Em se admitindo a responsabilidade civil coletiva, tema tratado por Fernando de Noronha ${ }^{96}$, na qual um

93 Entre aqueles que só admitem a ação coletiva para tutela de interesses metaindividuais cita-se Camilo Zufelato ZUFELATO, Camilo. Ação coletiva passiva no direito brasileiro: necessidade de regulamentação legal. In: GOZZOLI, Maria Clara et al. (Org.). Em defesa de um novo sistema de processos coletivos: estudos em homenagem a Ada Pellegrini Grinover. São Paulo: Saraiva, 2010. p. 92.

94 SHEN, Francis Xavier. The Overlooked Utility of the Defendant Class Action. Denver University Law Review, v. 88, p.73-181, 2010. Disponível em: <http://www.law.du.edu/ documents/denver-university-law-review/v88-1/Shen_FinalProof_21111.pdf >. Acesso em: 29 jul. 2012. p. 114.

95 SHEN, Francis Xavier. The Overlooked Utility of the Defendant Class Action. Denver University Law Review, v. 88, p.73-181, 2010. Disponível em: <http://www.law.du.edu/ documents/denver-university-law-review/v88-1/Shen_FinalProof_21111.pdf >. Acesso em: 29 jul. 2012. p. 114.

96 NORONHA, Fernando de. Direitos das obrigações: funda- ente coletivo responde por danos causados por membros não identificados do grupo, a tabela de Shen poderia ser útil em eventuais ações de regresso.

Tem-se notícia de que a responsabilidade coletiva é admitida no ordenamento chileno. Ela ocorreria quando não fosse possível identificar o autor ou os autores de determinado ato ilícito, mas se pudesse delimitar um grupo do qual os possíveis culpados sejam integrantes. Nesses casos, o autor poderia demandar qualquer um dos componentes do grupo, sendo que este poderá propor uma acción de reembolso contra aquele que entender ser o real culpado. ${ }^{97}$

\section{Subsídios para admissão de lege lata das ações coletivas passivas}

Como já dito, as ações coletivas passivas não estão expressamente previstas no ordenamento brasileiro. Porém, é inegável que nos últimos anos essas ações passaram a fazer parte da realidade do foro ${ }^{98}$, o que vem fomentando o crescente debate acerca do assunto. Obviamente, o mero ajuizamento desse tipo de ação por si só não justifica o desenvolvimento de pesquisas substanciais sobre o assunto, uma vez que, diante do irrestrito direito de petição, pode-se provocar o judiciário para que este se manifeste sobre demandas nitidamente infundadas. Nada obstante, a análise substancial da utilização das defedant class actions brasileiras revela que a maioria delas não se enquadra nessa hipótese.

Frise-se que as ações coletivas passivas, na medida em que o autor da demanda não precisa dementar individualmente cada um dos integrantes do grupo que lesionou ou ameaçou de lesão determinado direito, podem ser úteis, inclusive, para evitar decisões contraditórias e fomentar a economia de recursos financeiros.

Indiscutivelmente, o advento de regulamentação legal que norteie e delimite o âmbito de aplicação das ações coletivas passivas irá clarificar a atuação do opera-

mentos do direito das obrigações: introdução à responsabilidade civil. São Paulo: Saraiva, 2003. p . 492. v. 1.

97 GRINOVER, Ada Pellegrini; WATANABE, Kazuo; MULLENIX, Linda. Os processos coletivos nos países de civil lawe common law: uma análise de direito comparado. 2. ed. São Paulo: Revista dos Tribunais, 2011.p. 181.

98 É plausível afirmar que o velho problema das ações possessórias e petitórias propostas contra coletividades indeterminadas talvez seja o exemplo mais antigo de ação coletiva passiva. 
dor do direito diante das novas e peculiares situações que diuturnamente surgem na prática jurídica. Nessa linha, há posicionamento no sentido de que, como consequência lógica do amadurecimento do processo coletivo, a previsão expressa das ações coletivas passivas é uma tendência. ${ }^{99}$

Por ora, estamos de acordo com Jordão Violin, segundo o qual a falta de previsão legal específica para essas ações sucumbe diante dos ditames do acesso à justiça e do direito de ação. O referido autor ressalta ainda que não há de se falar em omissão legislativa absoluta, ao ponto de inviabilizar por completo o manejo das ações coletivas passivas, pelo contrário, pode-se - por meio da interpretação de regras positivadas - encontrar o fundamento dessas ações. ${ }^{100}$ Destarte, a seguir discorreremos sobre os dispositivos legais que viabilizam uma interpretação que enxergue o processo coletivo passivo como algo inerente ao sistema.

Ao tratar do assunto, Rodolfo de Camargo Mancuso faz remissão ao parágrafo único do inciso III do art. 295 do Código de Processo Civil. ${ }^{101}$ Ocorre que, na atual configuração do processo civil brasileiro, é possível pleitear qualquer pretensão que não seja juridicamente impossível. Seguindo esse raciocínio, não havendo no ordenamento vedação expressa à ação coletiva passiva, a viabilidade desta não deve ser afastada a priori.

Conforme Aluisio de Gonçalves de Castro Mendes, o mais basilar fundamento das ações coletivas passivas está na inafastabilidade do controle jurisdicional. ${ }^{102}$ São relevantíssimas as situações concretas que, em caso de negação da legitimação passiva da coletividade, restariam desprovidas de tutela. Reza o inciso XXXV do artigo 5. ${ }^{\circ}$ da Constituição Federal: a lei não excluirá da apreciação do judiciário lesão ou ameaça de direito.

Castro Mendes cita ainda a representatividade dos sindicatos, consagrada na Constituição de $1988 .{ }^{103}$

99 LEONEL, Ricardo de Barros. Manual do processo coletivo. 2. ed. São Paulo: Revista dos Tribunais, 2011. v. 1. p. 20

100 VIOLIN, Jordão. Ação coletiva passiva: fundamentos e perfis. Salvador: JusPodivum, 2008. p. 39-40.

101 MANCUSO. Rodolfo de Camargo. Ação civil pública. 12. ed. São Paulo: Revista dos Tribunais, 2011. p. 3.

102 MENDES, Aluisio Gonçalves de Castro. A legitimação, a representatividade adequada e a certificação nos processos coletivos e as ações coletivas passivas. Revista de Processo, v. 209, p. 243-265, 2012. p.261.

103 GRINOVER, Ada Pellegrini et al. Código brasileiro de defesa do consumidor: comentado pelos autores do ante-
De fato, o inciso III do art. 8..$^{\circ}$ da CF estabelece que ao sindicato cabe a defesa dos direitos e interesses coletivos ou individuais da categoria, inclusive em questões judiciais ou administrativas. Ora, nesse dispositivo o legislador não restringiu a representação sindical ao polo ativo da demanda, logo, é plausível justificar uma ação coletiva passiva no qual o sindicato atue como representante na classe com base no citado dispositivo constitucional.

Ada Pellegrini Grinover lembra que o art. 5..$^{\circ} \$ 2$ da Lei da Ação Civil Pública faculta às associações legitimadas e ao Poder Público à habilitação como litisconsortes de qualquer uma das partes. Segundo a processualista, esse litisconsórcio pode ser formado tanto no polo ativo como no polo passivo da demanda coletiva. ${ }^{104}$

Além disso, Grinover, ao buscar subsídios para admissão de lege lata para das ações coletivas passivas, invoca também o art. 107 do Código de Defesa do Consumidor, que trata das convenções coletivas de consumo. ${ }^{105}$ Tais convenções podem ser pactuadas por entidades civis de consumidores e associações de fornecedores ou sindicatos de categoria econômica. Sobre a ação duplamente coletiva ${ }^{106}$ cuja causa de pedir é o descumprimento da convenção coletiva de consumo, ensina Ada Pellegrini Grinover:

Ora, se a convenção coletiva (com ato bilateral que atribui direitos e obrigações), firmada entre a classe de consumidores e a de fornecedores, não for observada, de seu descumprimento originar-se-á uma lide coletiva, que só poderá ser solucionada em juízo pela colocação dos representantes da categoria face a face, no polo ativo e no polo passivo da demanda, respectivamente. ${ }^{107}$

projeto: processo coletivo. 10. ed. Rio de Janeiro: Forense Universitária, 2011. p. 263. v. 2.

104 GRINOVER, Ada Pellegrini et al. Código brasileiro de defesa do consumidor: comentado pelos autores do anteprojeto: processo coletivo. 10. ed. Rio de Janeiro: Forense Universitária, 2011. v. 2.p. 102

105 GRINOVER, Ada Pellegrini. et al. Código brasileiro de defesa do consumidor: comentado pelos autores do anteprojeto: processo coletivo. 10. ed. Rio de Janeiro: Forense Universitária, 2011. v. 2. p. 102

106 A expressão ação duplamente coletiva (ou bilateral, segundo a terminologia da common law) é usada para fazer referência às ações nas quais de ambos os lados existem interesses metaindividuais. TOZZI, Thiago Oliveira. Ação Coletiva Passiva: conceito, características e classificação. Revista de Processo, v. 205, p. 267-296, 2012. p.292.

107 GRINOVER, Ada Pellegrini et al. Código brasileiro de defesa do consumidor: comentado pelos autores do anteprojeto: processo coletivo. 10. ed. Rio de Janeiro: Forense Universitária, 2011. p. 103. 
Já Fredie Didier Jr. e Hermes Zaneti Jr., ao buscarem fundamentos para a admissão de lege lata das ações coletivas passivas recorrem ao art. 83 do CDC. ${ }^{108}$ Dispõe esse dispositivo legal: "para a defesa dos direitos e interesses protegidos por este código são admissíveis todas as espécies de ações capazes de propiciar sua adequada e efetiva tutela."

Ademais, a existência e admissão das ações coletivas passivas de lege lata no direito brasileiro, ainda que em hipóteses pontuais, podem ser balizadas pela compreensão das chamadas ações coletivas passivas derivadas ou incidentais. ${ }^{109}$ Castro Mendes elenca hipóteses de ações coletivas passivas derivadas, tais como as ações rescisórias ou embargos de terceiro. ${ }^{110}$ Mesmo Hugro Nigro Mazzili, crítico da admissão de lege lata das ações coletivas passivas, reconhece que em algumas hipóteses irremediavelmente legitimados ativos comporão o polo passivo da demanda, para tanto o processualista conjecturou o seguinte exemplo:

Uma execução de compromisso de ajustamento de conduta: se o executado apresentar embargos à execução, o exequente passará a figurar como embargado, ou seja, estará no polo passivo da ação de embargos, por meio do qual o executado quer desconstituir o título executivo. ${ }^{111}$

Tem-se notícia de julgados que reconheceram a legitimidade passiva do ente coletivo em sede de ação rescisória de ação coletiva. Nesse sentido foi o posicionamento adotado pelo Tribunal Regional Federal da 4. ${ }^{a}$ região no julgamento dos embargos infringentes em agravo regimental n. ${ }^{\circ}$ 95.04.33984-0/SC. ${ }^{112}$ In casu, o Instituto Brasileiro do Meio Ambiente e dos Recursos Naturais Re-

108 DIDIER JUNIOR., Fredie; ZANETI JUNIOR., Hermes. Curso de direito processual civil: processo coletivo. 4. ed. Salvador: Jus Podivm, 2009. p. 405-406.

109 Diogo Campos Mediana Maia chama de ações coletivas passivas derivadas ou incidentais [...] aquelas que, muito embora autônomas, justificam-se pela existência de uma ação coletiva ativa. MAIA, Diogo Campos Medina. Ação coletiva passiva. Rio de Janeiro: Lumen Juris, 2009. p. 122.

110 MENDES, Aluisio Gonçalves de Castro . A legitimação, a representatividade adequada e a certificação nos processos coletivos e as ações coletivas passivas. Revista de Processo, v. 209, p. 243-265, 2012. p. 261.

11 MAZZILLI, Hugo Nigro. A defesa dos interesses difusos em juízo: meio ambiente, consumidor, patrimônio cultural, patrimônio público e outros interesses. 24. ed. rev., ampl. e atual. São Paulo: Saraiva, 2011. p. 384.

112 BRASIL. Tribunal Regional Federal da 4. ${ }^{a}$ Região. Embargos Infringentes em AR N.o 95.04.33984-0-SC. Relator: Desembargador Federal Amaury Chaves de Athayde. nováveis (IBAMA) buscou a desconstituição de decisão favorável ao Sindicato dos Trabalhadores no Serviço Público Federal em Santa Cataria (SINTRAFESC) em ação coletiva. Na decisão que deu azo à oposição dos embargos infringentes restou vencida a Desembargadora Federal Sílvia Goraieb, que, em preliminar de mérito, manifestou-se no sentido de que dos trabalhadores beneficiados pelo processo original deveriam funcionar como litisconsortes do sindicato. Não obstante, os embargos infringentes opostos foram negados por unanimidade. Tomamos a liberdade de transcrever parte do corpo da decisão que versa sobre a impossibilidade da formação do litisconsórcio multitudinário no caso:

$\mathrm{Na}$ prática [em se admitido a necessidade de formação do litisconsórcio], far-se-iam absolutamente infensas a qualquer hostilização ulterior pela regular via da ação rescisória, eis que, apesar de a angularização processual na ação de origem, na ação de rescisão ter-se-ia de dilargar o polo passivo a contigentes até imensuráveis, impedindo o andamento do processo in concreto, máxime em linha de conta que a entidade sindical atua não só na substituição de seus filiados mais sim na substituição de toda a categoria que representa, consoante a letra da Constituição (CF, art. $8^{\circ}$, III).

As últimas linhas do trecho citado são dignas de nota ao passo que foi esboçada uma interpretação do inciso III do art. $8 .^{\circ}$ da Constituição Federal que reconhece a legitimidade dos sindicatos para representarem seus associados — ou ainda toda a categoria — inclusive, no polo passivo de uma demanda coletiva.

Encontramos julgado do Tribunal de Justiça do Espírito Santo que igualmente reconheceu a desnecessidade da formação de litisconsórcio em ação rescisória de ação coletiva. ${ }^{113}$ Inicialmente foi determinada a citação de todos os milhares de credores do precatório n. ${ }^{\circ}$ 20020000150, beneficiados pela decisão transitada em julgado no processo original. Porém, face à interposição de agravo regimental, o Desembargador relator exerceu o juízo de retratação e admitiu estar diante de uma defendat class action.

Ainda sobre as ações coletivas passivas derivadas, deve ser estudada a ação declaratória incidental

113 BRASIL. Tribunal de Justiça do Espírito Santo. Processo No 100080001728 - AGRAVO REGIMENTAL AC DECLARATÓRIA. Relator: Desembargador Dair José Bregunce de Oliveira. Diário da Justiça, Brasília, 19 jan. 2012. 
$100070019698^{114}$, decidia pelo pleno do Tribunal de Justiça do Espírito Santo. Na referida ação, buscou-se a declaração da inexigibilidade de obrigação decorrente de decisão fundada em lei ou ato normativo declarados inconstitucionais pelo Supremo Tribunal Federal - de acordo com a dicção do parágrafo único do art. 741 da codificação processual civil. Transcrevemos abaixo trecho do julgado que reconheceu a legitimidade passiva do ente coletivo:

A procedência da demanda coletiva passiva (defendant class action) afeta a esfera individual dos associados independentemente do exercício pessoal do contraditório. Com maior razão se participam, em polos invertidos, exatamente aqueles que figuraram na demanda geradora do ato objurgado.

\section{Conclusão}

Podemos concluir que, em que pese às construções pretorianas sobre as ações coletivas passivas originárias ainda sejam rarefeitas, a jurisprudência caminha no sentido do reconhecimento desse tipo de ação, especialmente no que toca às chamadas ações coletivas passivas derivadas. Obviamente, o processo coletivo originariamente foi pensado para proteger grupos, logo, a ação coletiva passiva ainda gera alguma perplexidade, que há de ser contornada pela academia e por futura regulamentação legal que delimite e norteie as defendant class actions brasileiras.

Nesse trabalho foram elencadas inúmeras possibilidades de utilização da ação coletiva, provavelmente muitas delas não sairão do papel por serem inviáveis ou por não resistirem a uma abordagem mais profunda. Nada obstante, a realidade brasileira demonstra que o espaço para aplicação das defendant class actions é amplíssimo e talvez esta via seja a mais adequada para tutelar determinados direitos que sofreram repetidas lesões ou ameaças de lesão.

\section{Referências}

ARENHART, Sérgio Cruz. A tutela coletiva de interesses individuais: para além da proteção dos interesses individuais homogêneos. São Paulo: Revista dos Tribunais, 2013.

114 BRASIL. Tribunal de Justiça do Espírito Santo; $A D$ 100070019698 ES 100070019698. Relator Samuel Meira Brasil Junior. Diário da Justiça, Brasília, 14 jul. 2008.
ARENHART, Sérgio Cruz. Perfis da tutela inibitória coletiva. São Paulo: RT, 2006.

MELLO, Celso Antônio. Curso de direito administrativo. 29. ed. São Paulo: Malheiros, 2012.

CINTRA, Antônio Carlos de Araújo; DINAMARCO, Cândico Rangel; GRINOVER, Ada Pellegrini. Teoria geral do processo. 26. ed. São Paulo: Malheiros, 2010.

CUNHA, Alcides Alberto Munhoz. Evolução das ações coletivas no Brasil. Revista de Processo, São Paulo, v. 77, p. 2-3, 1995.

DIDIER JUNIOR, Fredie; ZANETI JUNIOR, Hermes. Curso de direito processual civil: processo coletivo. 4. ed. Salvador: Jus Podivm, 2009.

DIDIER, Fredie. Situações jurídicas coletivas passivas: o objeto das ações coletivas passivas. Revista Eletrônica de Direito do Estado (REDE), Salvador, Instituto Brasileiro de Direito Público, n. 26, abr./jun. de 2011. Disponível em: <http://www.direitodoestado.com/revista/REDE26-ABRIL-2011-FREDDIE-DIDIER.pdf>. Acesso em: 9 maio 2013.

FISS, Owen. Um novo processo civil: estudos norteamericanos sobre jurisdição, constituição e sociedade. São Paulo: Revista dos Tribunais, 2004.

FORMACIARI, Flávia Hellmeister Clito. A representatividadeadequada nos processos coletivos. 2009. 189 f. Tese (Doutorado) - Programa de Pós Graduação em Direito da Universidade de São Paulo. Disponível em: $<$ www.teses.usp.br/.../Representatividade_Adequada_ nos_Processos_Coletivos.pdf $>$. Acesso em: 29 jul. 2012.

GIDI, Antonio. A Class Action como instrumento de tutela coletiva dos direitos. São Paulo: Revista dos Tribunais, 2007.

GIDI, Antonio. Class Actions in Brazil: a model for civil law countries. The America Journal of Comparative Law, v. 51, p. 311-408, 2003. Disponível em: <http:// www.temple.edu/lawschool/iilpp/images/PDFs/ GidiGidiClassActions.pdf>. Acesso em: 29 jul. 2012.

GIDI, Antonio. Rumo a um código de processo civil coletivo: a codificação das ações coletivas no Brasil. Rio de Janeiro: Forense, 2008.

GRINOVER, Ada Pellegrini. A ação civil pública refém do autoritarismo. Revista de Processo, v. 96, p. 28-36, 1999.

GRINOVER, Ada Pellegrini et al. Código brasileiro de defesa do consumidor: comentado pelos autores do anteprojeto. 4. ed. Rio de Janeiro: Forense Universitária, 1995. 
GRINOVER, Ada Pellegrini et al. Código brasileiro de defesa do consumidor: comentado pelos autores do anteprojeto: processo coletivo. 10. ed. Rio de Janeiro: Forense Universitária, 2011.

GRINOVER, Ada Pellegrini; WATANABE, Kazuo; MULLENIX, Linda. Os processos coletivos nos países de civil law e common law: uma análise de direito comparado. 2. ed. São Paulo: Revista dos Tribunais, 2011.

GROSSI, Paolo. L'Europa del diritto. 6. ed. Roma-Bari: Laterza, 2010.

LEITE, Carlos Henrique Bezerra. Curso de direito processual do trabalho. 10. ed. São Paulo: LTr, 2012.

LEONEL, Ricardo de Barros. Manual do processo coletivo. 2. ed. São Paulo: Revista dos Tribunais, 2011.

MAIA, Diogo Campos Medina. Ação coletiva passiva. Rio de Janeiro: Lumen Juris, 2009.

MANCUSO. Rodolfo de Camargo. Ação civil pública. 12. ed. São Paulo: Revista dos Tribunais, 2011.

MARINONI, Luiz Guilherme; ARENHART, Sérgio Cruz. Curso de processo civil: procedimentos especiais. 3. ed. São Paulo: Revista dos Tribunais, 2012.

MAZZILLI, Hugo Nigro. A defesa dos interesses difusos em juizo: meio ambiente, consumidor, patrimônio cultural, patrimônio público e outros interesses. 24. ed. rev., ampl. e atual. São Paulo: Saraiva, 2011.

MENDES, Aluisio Gonçalves de Castro. A legitimação, a representatividade adequada e a certificação nos processos coletivos e as ações coletivas passivas. Revista de Processo, v. 209, p. 243-265, 2012.

MENDES, Aluisio Gonçalves de Castro. Ações coletivas no direito comparado e nacional. São Paulo: Revista dos Tribunais, 2002.

NETTO, Nelson Rodrigues. Subsídios para a ação coletiva passiva brasileira. Revista de Processo, v. 149, p. 79-104, 2007.
NETTO, Nelson Rodrigues. The use of Defendant Class Actions to protect rights in the Internet. Panóptica, Vitória, v. 1, p. 3, 2007.

NORONHA, Fernando de. Direitos das obrigações: fundamentos do direito das obrigações: introdução à responsabilidade civil. São Paulo: Saraiva, 2003.

ROSSI, Júlio César. A ação coletiva passiva. Revista de Processo, v. 198, p. 259-280, 2011.

SANTOS, Ronaldo Lima dos. "Defendant Class Actions": O grupo como legitimado passivo no direito norteamericano e no Brasil. Boletim Científico da Escola Superior do Ministério Público da União, Brasília, p. 150, jan./mar 2004.

SHEN, Francis Xavier. The overlooked utility of the Defendant Class Action. Denver University Law Review, v. 88, p.73-181, 2010. Disponível em: <http://www.law. du.edu/documents/denver-university-law-review/v88-1/ Shen_FinalProof_21111.pdf>. Acesso em: 29 jul. 2012.

TOZZI, Thiago Oliveira. Ação coletiva passiva: conceito, características e classificação. Revista de Processo, v. 205, p. 267-296, 2012.

VENTURI, Elton. Processo civil coletivo: a tutela jurisdicional dos direitos difusos, coletivos e individuais homogêneos no Brasil. Perspectivas de um Código Brasileiro de processos coletivos. São Paulo: Malheiros, 2007.

VINCENZO, Vigoriti. Interessi colletivi e processo: la legittimazione ad agire. Milão: Giuffrè, 1979.

VIOLIN, Jordão. Ação coletiva passiva: fundamentos e perfis. Salvador: JusPodivum, 2008.

ZUFELATO, Camilo. Ação coletiva passiva no direito brasileiro: necessidade de regulamentação legal. In: GOZZOLI, Maria Clara et al. (Org.). Em defesa de um novo sistema de processos coletivos: estudos em homenagem a Ada Pellegrini Grinover. São Paulo: Saraiva, 2010. 